Krajnak, M. (2019). Do Selected Tax Advantages Affect Tax Revenue from the Personal Income Tax?

Journal of Competitiveness, 11(4), 73-88. https://doi.org/10.7441/joc.2019.04.05

\title{
DO SELECTED TAX ADVANTAGES AFFECT TAX REVENUE FROM THE PERSONAL INCOME TAX?
}

\section{- Michal Krajnak}

\begin{abstract}
The personal income tax, which has a significant influence on total tax revenue, has been part of the Czech tax system since 1993. The main objective of this paper is to evaluate the dependence of tax revenue on the personal income tax based upon a dependent activity related to tax relief for the taxpayer, namely the tax credit for children in the Czech Republic in the period of 2008 - 2017. Another objective is to analyze the dependence on the valorization of the tax reliefs and tax credit claims. The database of the Czech Statistical Office and the Ministry of Finance of the Czech Republic is used as a source of input data for the analysis. To achieve the objectives of the paper, methods of description, comparison, analysis, synthesis, as well as regression and correlation analyses are used. The results of the analysis show that the tax credit for children has a positive effect on tax revenue. The amount of the tax advantage for children has almost doubled in the last 11 years. On the other hand, general tax relief for all taxpayers has not been valorized since 2008. The existence of a certain non-taxable minimum is typical for personal income tax systems around the world tax, and the valorization in the Czech Republic did not show a negative impact on the tax system's competitiveness. Increasing the amount of deductions might be non-effective from the perspective of the state, but the results of this study show that the effect on personal income tax revenue in the Czech Republic is the opposite. The projected value and uniqueness of the article is not only in the analysis of dependencies of selected tax allowances upon each other, but also in the context of tax revenue and selected macroeconomics indicators.
\end{abstract}

Keywords: Czech Republic, personal income tax, tax income, tax credit, competitiveness JEL Classification: C50, H24, H71, K34

Received: July, 2019

1st Revision: October, 2019

Accepted: October, 2019

\section{INTRODUCTION}

Income tax has been part of the tax system of the Czech Republic since the nation's split with Slovakia in 1993, with the income tax of individuals considered a personal income tax in the Czech Republic. Legislation regarding the income tax of natural persons undergoes yearly changes, e.g. in the form of adjustments to deductions or tax rates have cause the taxpayer's tax burden to change almost every year. 
One of the ways for the taxpayer to achieve a lower tax burden is to use tax deductions, When the individual's actual tax burden is reduced through deductions, however, overall tax revenue also falls. According to Wilson (1999), in order for the tax system to be competitive, it should be able to stimulate an increase the number of contributors to the overall tax base via related legislation. A positive effect of this competition is the effort to reduce individual tax burden, e.g. by tax reliefs.

Tax reliefs, non-taxable exemptions and other deductions are crucial for taxpayers to optimize their tax liability. Sorensen (2004) describes typical examples of setting a minimum income limit, below which is non-taxable, along with the institution of personal exemptions as well as deductions and credits for children. As a result of these mitigating structures, a certain portion of personal income is not taxed at all.

The main objective of this paper is to evaluate the dependence of overall tax revenue from 2008 - 2017 on a personal income tax in terms of one form of tax relief: the tax credit for children in the Czech Republic. The potential value of this paper is that the analysis of dependence is conducted not only in terms of comparing tax revenue with tax reliefs or tax credits, but also among other macroeconomics indicators such as the rate of registered unemployment and the pace of economic growth. To the author's knowledge, this type of study specifically dealing with the tax legislation of the Czech Republic legislation has not been undertaken yet. Another objective of this research is to analyze the dependence of the valorization of the tax reliefs and tax credit.

The Organization for Economic Cooperation and Development uses taxpayer income to compare the tax burden in terms of the application of deductions in the form of the non-taxable part of the tax base and tax relief for the taxpayer (OECD, 2019). Another tax-alleviating structure widely used by Czech taxpayers is the deduction for children (Zubalová, 2015).

The key scientific hypothesis for this research was that the tax relief for the taxpayer and the tax credit for children negatively affect the total tax revenue from the personal income tax based on a dependent activity. The analyzed period is limited to the years 2008 and 2017. The year 2008 was chosen because of the significant reform of public finances instituted in the Czech Republic on 1 January 2008. These changes significantly influenced not only the tax burden on taxpayers, but also tax revenue (Havránek et al., 2016). The year 2017 represents the last year with data sets available.

The introduction of the article is followed by an outline of the theoretical background with a focus on the personal income tax. The succeeding part is focused on the characteristics of the methods and input data used in the third section, in which the application of the data is described. The fourth chapter communicates the results and discussion, with the conclusion presented in section five.

\section{THEORETICAL BACKGROUND}

Research studies and other scientific literature investigate particular facets within the field of personal income tax from various macroeconomic as well as microeconomic points of view. A progressive tax indicates that the individual tax burden increases along with the growth of 
the taxpayer's income (Heathcote et al., 2017; Oh, 2017; Fu et al., 2019). A progressive personal income tax is a typical feature of most of the world tax systems. The personal income tax in the Czech Republic is also progressive, not because of the tax rates, but due to the tax allowances, reliefs and credits that have been instituted (Friedrich et al., 2012). The personal income tax is an important tool for redistributing the income of natural persons (Aidt \& Jensen, 2009; Verbist \& Figari, 2014; Belozyorov \& Sokolovska, 2018).

Legislation regulating the taxation of income from employment has of course not only undergone changes in the Czech Republic, but also in numerous national systems. Due to these changes, the amount of tax burden fluctuates. Nam \& Zeiner (2016) state that one problem with progressive rates of personal income tax is the indexation of inflation. Despite the increase in nominal wages, the taxpayer in turn moves into higher tax brackets, thus a situation may occur in which despite the growth of gross earnings the net income may be lower. On the other hand, increasing the tax credit also increases the number of people who pay no tax, the results of which are described by Splinter (2019).

The personal income tax as it functions in the Czech Republic was the subject of research by Večerník (2006), who confirmed that this tax is an important instrument for redistribution of revenues, although the Czech tax burden from this instrument is below the European Union average. The changes in the legislative framework regulating the field of direct taxation in the context of personal income tax in the Czech Republic have been studied by Tepperová \& Pavel (2016). Data from the years 1994 to 2014 were used to create three models quantifying the impact of the changes on the income tax as well as on social and health insurance. A total of three income tax reforms were defined as statistically significant using regression models. A positive dependence between wage level and tax revenues was confirmed. The most significant impact on the revenues of public budgets was that of the reform in 2008, which caused a revenue decrease of EUR 24 billion CZK along with accompanying budget cuts. A similar decrease in the revenues of public budgets was caused by a reform in the year 2006, when the tax-free income allowance was replaced by a tax credit system. In the context of this reform, other taxes have also been modified, e.g. a real property transfer tax was instituted (Široký et al., 2016). The personal income tax in the Czech Republic represents a significant part of the public budget revenue (Andrlík, 2014).

The personal income tax remains a key research area not only in the Czech Republic, but also in the context of other national tax systems around the world, with the personal income tax consistently found to be an important source of public revenues (Zimcik, 2016). The total sum of tax revenue also depends on many other tax attributes, e.g. non-taxable income and tax reliefs (Breuer, 2010; Fricke \& Süsssmüth, 2014). Another factor is the tax rate. Lee \& Gordon (2005) provide evidence showing that a low corporate rate leads to a fall in personal income tax revenue, in spite of the higher growth rate. They presume this occurs because people reduce their time as employees, where income is the subject to the personal tax, and instead become entrepreneurs, thus generating corporate tax revenue. Statistics of tax revenue can be a tool to determine an appropriate method of calculating tax rates (Mendoza et al., 1994).

The impact of the tax and social system in the context of tax deductions on income distribution was the subject of study carried out by Schneider \& Jelínek (2005). Their results show that the 
most significant impact of tax deductions is in the decile of the lowest income groups of taxpayers. On the contrary, in the last - tenth decile, the impact of tax reliefs on the revenue growth is only $3.9 \%$. The authors of the study recommend that other items that are in the form of tax-free income allowance or items deductible from the tax bases are converted into a form of tax credit with the possibility of creating a tax bonus as is the case under current legislation in 2019 in the case of a tax advantage for children living with a taxpayer in a household. A motivation for working can be tax credits for low earners taxpayers (Blundell \& Shephard, 2012). Bird \& Zolt (2005) confirm this fact that the tax cannot be too progressive in many developing countries. The level of wage in developing countries is too low and due to existence of tax credits, the level of tax progression for low-income wages is not high.

Tax reforms often change the technique of income taxation, with regard to often changing tax deductions, whether in the form of tax credits or tax-free income allowances. In the Czech Republic, substantial adjustments were made in taxation of incomes of natural persons from employment in 2008 (Vlachý, 2008). This year, the progressive rate of tax was replaced by a linear rate. This technique of income taxation has been in force until now (year 2019). The results obtained by Vítek (2012) or Vítek \& Pavel (2013) indicate that the abolition of these progressive rates has led to a decrease in the progressivity of the personal income tax. Nevertheless, the personal income tax in the Czech Republic remains progressive and constitutes a significant proportion of the state's tax revenue. In terms of the stability of the country's economic policy, it is beneficial if the tax revenue of the individual taxes of the country's tax system does not exhibit high volatility (Cornia et al., 2017). At the same time, the state seeks to maximize the tax revenue (Angelopoulos et al., 2019; Creedy \& Germmell, 2015). The results of Morini \& Pellegrino (2018) show that in Italy, there is a reduction of the tax revenue.

Sobotovičová \& Blechová (2017) found that tax revenues in the Czech Republic are affected by legislative changes, but also by geographic or demographic differences among the regions. In addition to tax deductions or progressiveness, the tax revenue is also affected by other variables. The dependence of tax revenues on macroeconomic factors such as the gross domestic product (GDP) was analysed by Bezdek \& Stiller (2000). The conclusions of the model show that tax revenue is increasing as the GDP grows. Important factors for tax systems are political variables (Profeta \& Scabrosetti, 2017). Other factors also include the wage level (Yilmazkuday, 2017) or tax burden in neighbouring countries (Swank, 2016).

Tax policy influences the economic growth or employment, which was found by Andrasic et al., (2018). According to the results of this study or the study by Gale \& Potter (2002), tax policy has a positive effect on the economic growth. On the other hand, Kotlán \& Machová (2013) or Izák (2011) found that taxation has a negative impact on the economic growth. The tax structure and height depends not only on the economic growth but also on the amount of public debt (Holko, 2019).

Direct taxes are important tools of fiscal policy. Increases in labor taxes have an asymmetric impact on employment (Berger \& Evaraert, 2013). A high level of unemployment has a negative effect on tax revenue (Shi \& Wen, 1999). Dolenc et al., (2011) examined the labor taxation from a dependent activity in Croatia compared to the taxation of workers in other OECD countries. Their empirical analysis shows that Croatia should continue with reducing tax burden because this situation stimulates job creation and would reduce the rate of unemployment. On the con- 
trary, Bohringer et al., (2005) states that the taxation as a tool for reducing the unemployment does not have a significant effect.

\section{RESEARCH OBJECTIVE, METHODOLOGY AND DATA}

To achieve the objective of the paper, the author used standard positivist economic methodology which also included the scientific methods of description, deduction, comparison, as well as study of legal sources and finally, synthesizing methods. For a specific analysis of dependency between the examined factors, the correlation and regression analyses were used.

\subsection{Methodology}

The study of dependence between two or among more statistical features is dealt with by means of the regression and correlation analyses. The principle of regression is in seeking a regression function in the form (1),

$\tilde{y}=c_{1} f_{1}(x)+c_{2} f_{2}(x)+\ldots+c_{m} f_{m}(x)=\sum_{j=1}^{m} c_{j} f_{j}(x)$,

i.e. a linear combination of selected functions $f_{1}(x), f_{2}(x), \ldots, f_{m}(x)$ with unknown parameters $c_{1}, c_{2}$, ..., $c_{m}$. For modelling dependence of tax revenue and tax relief on the taxpayer and the tax credit for children, model (2) is formed,

$Y=\beta_{0}+\beta_{1} X_{1}+\beta_{2} X_{2}+\beta_{3} X_{3}+\varepsilon$

where $\mathrm{Y}$ is the dependent variable expressing the amount of recalculated tax revenue in CZK to the price level of the year 2017, $X_{1}$ is a recalculated tax relief on the taxpayer or the tax credit for the first, second or third child, $X_{2}$ is the rate of registered unemployment, $X_{3}$ is the pace of economic growth and $\varepsilon$ is the random component of the model. The article also analyses the dependence of the share of tax revenue on the income tax from a dependent activity to the total tax revenue and tax relief on the taxpayer. In general, the model is determined by (3),

$Y=\beta_{0}+\beta_{1} X_{1}+\varepsilon$,

where $\mathrm{Y}$ is the dependent variable expressing the share of tax revenue of the personal income tax from a dependent activity to the total tax revenue of the Czech Republic, $X_{1}$ is a recalculated tax relief on the taxpayer and $\varepsilon$ is the random component of the model.

The analysis of the dependence of two or more selected values is carried out by the correlation analysis. One of the most commonly used indicators is the Pearson correlation coefficient $r$ (4),

$r=\frac{\sum_{i=1}^{n}\left(x_{i}-\bar{x}\right)\left(y_{i}-\bar{y}\right)}{\sqrt{\sum_{i=1}^{n}\left(x_{i}-\bar{x}\right)^{2} \sum_{i=1}^{n}\left(y_{i}-\bar{y}\right)^{2}}}$

where $\tilde{\mathrm{x}}$ and $\tilde{\mathrm{y}}$ are sample averags. For more details about the regression and correlation analysis, see Teixeira \& Ferreira (2019) or Brase \& El-Iraki (2019).

\subsection{Data}

For the purposes of analysis of the interdependencies between the selected indicators, the following resources have been applied: 
- tax revenue of the personal income tax from a dependent activity in the Czech Republic from 2008 to 2017 and total tax revenue were sourced from Financial Administration (Financial Administration, 2019),

- the inflation rate, rate of registered unemployment and the pace of economic growth were sourced from the Czech Statistical Office (Czech Statistical Office, 2019),

- tax credits and tax reliefs from Act. No. 586/1992 Coll. on Income Taxes.

\section{RESULTS AND DISCUSSION}

One of the instruments to minimize the taxpayer's tax liability is to deduct either in the form of a tax-free income allowance or a tax credit. Since 2008, the deduction for the taxpayer has had the form of a tax relief. Also other deductions e.g. for a student or a disabled person are in the form of a tax relief. Deduction for children is in the form of a tax credit. Prior to the actual assessment of whether the most commonly used deductions (deduction for the taxpayer and for children) affect tax revenue, an analysis will be carried out to assess the interdependence of changes in the amounts of deductions that a natural person can use to reduce the tax liability.

\subsection{The analysis of the development of tax credits and tax advantages}

Tax reliefs and credits are widely used instruments to optimize the taxpayer's tax liabilities. Their absolute amount in the crown denomination, with the exceptions, remained unchanged in the analysis period between the years 2008 - 2019. However, this fact is not applicable in the case of tax credit, where, in recent years in particular, there has been a significant increase in the amount and its graduation according to the number of children per common household.

Table 1 shows the recalculated amounts of the tax reliefs and credit to the price level of 2008, i.e. after considering the inflation rate (Czech Statistical Office, 2019) per individual year. These figures show that in the majority of cases, there is a decrease in these amounts in the real crown denomination. As the tax rate and the method of construction of the tax base do not change, that the tax burden of natural persons is gradually increasing.

Tab. 1 - Recalculated tax reliefs and tax credit in CZK. Source: own research

\begin{tabular}{|l|l|l|l|l|l|l|l|l|l|}
\hline Year & TP & OS & PIP & FDP & SD & STU & 1 CH & 2 CH & 3 CH \\
\hline 2008 & 24840 & 24840 & 2520 & 5040 & 16140 & 4020 & 10680 & 10680 & 10680 \\
\hline 2009 & 23368 & 23368 & 2371 & 4741 & 15183 & 3782 & 10047 & 10047 & 10047 \\
\hline 2010 & 23150 & 23150 & 2349 & 4697 & 15042 & 3747 & 10815 & 10815 & 10815 \\
\hline 2011 & 21728 & 22831 & 2316 & 4632 & 14835 & 3695 & 10665 & 10665 & 10665 \\
\hline 2012 & 22439 & 22439 & 2276 & 4553 & 14580 & 3631 & 12108 & 12108 & 12108 \\
\hline 2013 & 21789 & 21789 & 2211 & 4421 & 14158 & 3526 & 11758 & 11758 & 11758 \\
\hline 2014 & 21525 & 21525 & 2184 & 4367 & 13986 & 3484 & 11615 & 11615 & 11615 \\
\hline 2015 & 21451 & 21451 & 2176 & 4352 & 13938 & 3472 & 11575 & 13648 & 14684 \\
\hline 2016 & 21395 & 21395 & 2171 & 4341 & 13902 & 3463 & 11545 & 14646 & 17747 \\
\hline
\end{tabular}




\begin{tabular}{|l|l|l|l|l|l|l|l|l|l|}
\hline 2017 & 21267 & 21267 & 2158 & 4315 & 13818 & 3442 & 11476 & 16613 & 20723 \\
\hline 2018 & 20821 & 20821 & 2112 & 4225 & 13529 & 3370 & 12744 & 16265 & 20288 \\
\hline 2019 & 20461 & 20461 & 2076 & 4152 & 13295 & 3311 & 12524 & 15984 & 19937 \\
\hline$\Delta \mathrm{CZK}$ & -4379 & -4379 & -444 & -888 & -2845 & -709 & 1844 & 5304 & 9257 \\
\hline$\Delta \%$ & -17.63 & -17.63 & -17.63 & -17.63 & -17.63 & -17.63 & 17.26 & 49.66 & 86.68 \\
\hline
\end{tabular}

The analysis results show that all of these tax reliefs mentioned, after consideration of inflation in the economy are decreasing in the real amount, as they are not valorized. The most widely used relief for the taxpayer has been reduced in the absolute crown denomination. The opposite trend of development can be observed in the case of a tax credit for children. Compared with the first analysed year 2008, all amounts have increased in 2019, the increase with growing numbers of children is more notable. This trend is dominating, especially since 2015, when the amount of deduction has increased with the growing number of children, while the amount for each child was equal until 2015. The results confirm the conclusions of the Nam \& Zeiner study (2016) that the fair value of these rebates is decreasing due to rising wages and inflation in economy.

The extent to which the relation between the amounts of tax reliefs or tax credit is significant is being analysed by the coefficient $r$, the values of which are shown in Table 2 .

Tab. 2 - Correlation matrix. Source: own research

\begin{tabular}{|l|l|l|l|l|l|l|l|l|l|}
\hline & TP & OS & PIP & FDP & SD & STU & $1 \mathrm{CH}$ & $2 \mathrm{CH}$ & $3 \mathrm{CH}$ \\
\hline TP & 1 & & & & & & & & \\
\hline OS & 0.9546 & 1 & & & & & & & \\
\hline PIP & 0.9546 & 1 & 1 & & & & & & \\
\hline FDP & 0.9546 & 1 & 1 & 1 & & & & & \\
\hline SD & 0.9546 & 1 & 1 & 1 & 1 & & & & \\
\hline STU & 0.9546 & 1 & 1 & 1 & 1 & 1 & & & \\
\hline $1 \mathrm{CH}$ & -0.5948 & -0.6923 & -0.6923 & -0.6923 & -0.6923 & -0.6923 & 1 & & \\
\hline $2 \mathrm{CH}$ & -0.6318 & -0.7170 & -0.7170 & -0.7170 & -0.7170 & -0.7170 & 0.5531 & 1 & \\
\hline $3 \mathrm{CH}$ & -0.5843 & -0.6605 & -0.6605 & -0.6605 & -0.6605 & -0.6605 & 0.4409 & 0.9885 & 1 \\
\hline
\end{tabular}

The direct linear dependence exists between a relief for the other spouse (OS), partial invalidity pension (PIP), full disability pension (FDP), severely disabled (SD) and student rebate (STU). None of these amounts increased or decreased in the absolute amount have since the public finance reform in 2008, but their value has been decreasing due to inflation.

A linear correlation close to 1 is between a relief for the taxpayer (TP) and PIP or FDP, SD, STU, and OS. This is because the relief for the taxpayer has temporarily decreased only in one tax period, otherwise it remains the same throughout the whole analysed period. Between the most widely used reliefs for TP and tax credit for children, there exists the indirect dependence of a different strength. The strongest dependence is between a relief for TP and a second child's tax credit $(2 \mathrm{CH})$. In case of the amount for the first child $(1 \mathrm{CH})$ and the third child $(3 \mathrm{CH})$, the 
indirect dependence is slightly lower. The reason for the indirect dependence is the fact that the amount for the taxpayer has not changed, except for one analysed year, the amounts for children have increased several times.

\subsection{Tax relief for the taxpayer, tax credit and tax revenue}

According to the Financial Administration (2018), the income tax of natural persons from employment has roughly reached a $20 \%$ share of tax revenues in the analysed period, while the EU-15 average was 25.2\% (Eurostat, 2018). Table 3 provides more detailed information on the percentage of tax revenue as well as on the revenue in the crown denomination. In 2009, the total tax revenue of the Czech Republic decreased in comparison with the year 2008, confirming the conclusion of the study by Caminada \& Goudswaard (1996) that the tax reform has a negative effect on revenue in the second period after this reform.

Tab. 3 - Recalculated tax revenue (TR) on the price level of the year 2017. Source: own research according to the Financial Administration (2018)

\begin{tabular}{|l|l|l|l|l|l|}
\hline Year & 2008 & 2009 & 2010 & 2011 & 2012 \\
\hline Tax Revenue in mil. CZK & 115180 & 104461 & 104233 & 109718 & 108209 \\
\hline Share on TR in \% & 18.97 & 21.23 & 20.39 & 21.26 & 20.52 \\
\hline Year & 2013 & 2014 & 2015 & 2016 & 2017 \\
\hline Tax Revenue in mil. CZK & 110644 & 113403 & 117552 & 128675 & 144898 \\
\hline Share on TR in \% & 20.65 & 20.47 & 20.30 & 20.40 & 21.51 \\
\hline
\end{tabular}

The components of the model of dependencies of recalculated tax revenue on the tax relief for the taxpayer and the tax advantage for children, which is generally formalized by the equation (2), are shown in Table $4 \mathrm{a}$ and Table $4 \mathrm{~b}$.

Tab. $4 \mathrm{a}$ - The Regression Analysis results. Source: own research

\begin{tabular}{|l|l|l|l|l|}
\hline & \multicolumn{2}{|l|}{ Model 1 - taxpayer } & \multicolumn{2}{l|}{ Model 2 - 1st child } \\
\hline Variables & Signif. & Coefficient & Signif. & Coefficient \\
\hline $\mathrm{X}_{1}$ & 0.027 & -3.524 & 0.191 & 4.372 \\
\hline $\mathrm{X}_{2}$ & 0.000 & -7396.6 & 0.002 & -7499.06 \\
\hline $\mathrm{X}_{3}$ & 0.587 & -339.8 & 0.781 & -233.37 \\
\hline Constant & 0.000 & 237022 & 0.016 & 109784 \\
\hline Observation & 10 & & 10 & \\
\hline R ${ }^{2}$ & 0.965 & & 0.938 & \\
\hline Signif. F & 0.000643 & 0.00347 & \\
\hline DW & 1.686 & 1.342 & \\
\hline
\end{tabular}


Tab. 4b - Regression Analysis results. Source: own research

\begin{tabular}{|l|l|l|l|l|}
\hline & \multicolumn{2}{|l|}{ Model 3 - 2nd child } & Model 4 - 3rd child \\
\hline Variables & Signif. & Coefficient & Signif. & Coefficient \\
\hline $\mathrm{X}_{1}$ & 0.008 & 3.318 & 0.005 & 2.150 \\
\hline $\mathrm{X}_{2}$ & 0.012 & -4172.43 & 0.032 & -3384.35 \\
\hline $\mathrm{X}_{3}$ & 0.687 & -201.119 & 0.988 & 6.435 \\
\hline Constant & 0.0007 & 99151.5 & 0.00153 & 106871 \\
\hline Observation & 10 & 10 & \\
\hline $\mathrm{R}^{2}$ & 0.976 & 0.980 & \\
\hline Signif. F & 0.000205 & 0.00013 & \\
\hline DW & 2.19 & 2.11 & \\
\hline
\end{tabular}

The regression analysis result for models 1 and 2 are not statistically significant, as the DW value indicates the autocorrelation of data (for more about Durbin-Watson test, see Hassler \& Hosseinkouchack, 2005; Lee, 2016). This is mainly due to the fact that time delays are incurred as economic policy instruments are measured and researched (Sims, 1996). Another problem of both models 1 and 2 is the significance level of some variables, which is higher than 0.05 .

On the other hand, the results of model 3 and 4 are statistically significant. It was found that the tax revenue of personal income tax depends on the tax credit for the second, respectively third child $\left(\mathrm{X}_{1}\right)$, as well as on the unemployment rate $\left(\mathrm{X}_{2}\right)$.

In model 3, the unemployment rate has shown a negative effect on tax revenue, while the tax credit for children was demonstrated to increase tax revenue. The same conclusions also apply regarding model 4 . Variable $\mathrm{X}_{3}$, i.e. pace of economic growth, was statistically insignificant and thus removed from the model. Equations expressing the dependence of the tax revenue on the mentioned variables take the form of (5) and (6),

$\mathrm{Y}=3,318 \mathrm{X}_{1}-4172,43 \mathrm{X}_{2}+99151,5$

$\mathrm{Y}=2,150 \mathrm{X}_{1}-3384,35 \mathrm{X}_{2}+106871$.

According to McClave \& Sincich (2018), the significant level is determined at the level of 5\%. The F-test value and the Durbin-Watson test results for (5) and (6) are in conformity. The coefficient of determinations evaluating the model's explanatory value indicates that about $98 \%$ of dependencies are described by this equation.

If the state seeks to maximize its tax revenue, it is advisable to continue with the established trend in the Czech Republic in the past years regarding the valorization of the amounts of tax credit for children. Increasing the tax credit for children is therefore a much more effective motivational tool for citizens to secure employment as compared to, e.g. increasing social benefits. This conclusion is consistent with the results from across Europe published by Abraham (1999). Instituting a tax bonus has a positive effect on taxpayer income from employment at or slightly above the minimum wage level. The tax bonus has been found to increase the preference of citizens to work rather than receive social benefits (Neverauskiene et al., 2017). 


\subsection{The dependence of the share of tax revenue in terms of an allowance for the taxpayer in the context of total tax revenue}

The allowance for the taxpayer is a guarantee of a certain minimum tax threshold of a taxpayer (Eissa \& Liebman, 1996; Kubátová \& Jareš, 2011). In case of the taxation of income from employment, each taxpayer is entitled to this allowance if he or she is a resident of the Czech Republic, with the incomes from resources within the territory of the Czech Republic generating at least $90 \%$ of the total income from individual taxpayers. For this reason, this is the most widely used allowance.

A generally formalized model is therefore formed by (3), with the specific value of this model captured in Table 5. For the purpose of this analysis, the significance level in accordance with Bonamente (2017) is selected at the level of $10 \%$.

Tab. 5 - The Regression Analysis results. Source: own research

\begin{tabular}{|l|l|l|}
\hline & Model 1 \\
\hline Variables & Signif. & Coefficient \\
\hline $\mathrm{X}_{1}-$ taxpayer & 0.065 & -0.000003672 \\
\hline Constant & 0.000 & 0.288 \\
\hline Observation & 9 & \\
\hline $\mathrm{R}^{2}$ & 0.603 \\
\hline Signif. F & 0.065 & \\
\hline DW & 1.891 & \\
\hline
\end{tabular}

The equations reflecting the dependence of the percentage of income tax revenue of natural persons from employment on the total revenue takes the form of (7), where

$\mathrm{Y}=0,288-0,000003672 \mathrm{X}_{1}$.

It is apparent from the determined equation that the allowance for the taxpayer $\mathrm{X}_{1}$ has a negative impact on the share in the tax revenue, and if that allowance did not exist, the share in the tax revenue in relation to the other taxes levied would be higher (about $29 \%$ ), a result which would, conversely, exceed the average for European Union countries.

The F-test value and the Durbin-Watson test results are in conformity. The F-test value (Signif. F) falls below the level of significance; the DW value indicates no autocorrelation. The significance level of variable $\mathrm{X}_{1}$ and the constant is not higher than the selected significance level, therefore the given variable in the model is well-founded. The coefficient of determination $\mathrm{R}^{2}$ has a lower value compared to the previous models (5) or (6), since almost $40 \%$ of the variance does not arise from the described dependency.

If the state wishes to increase its share of this tax in the form of tax revenue, the reduction of the taxpayer's allowance may be a way to achieve this. This increase in the tax burden could subsequently be compensated for by a lower tax burden in other areas, e.g. in the field of value added tax, which is dealt with to a greater degree by Krzikallová \& Stř́llková (2016). 


\section{CONCLUSION}

The main aim of the article has been to determine whether the tax relief for the taxpayer, specifically the tax credit for children in the personal income tax, affects the tax revenue of said tax. The personal income tax significantly contributed to the tax revenues in the Czech Republic during the entire period analyzed. Aside from 2008, the first year considered, the share exceeded one fifth of the total tax revenue.

Taxpayers use the options regulated by taxation legislation regarding the income of natural persons to optimize and minimize their tax burden. Examples of these instruments are the personal tax deduction as well as deductions reflecting the social status of the taxpayer (e.g. deductions for disability, student status, children, etc.). The results of the analysis show that the nominal amount of all tax reliefs did not change compared to the base year analyzed. However, if cost of living increases in the economy are taken into account, the real amount of these deductions is decreasing, and the taxpayer's tax burden is increasing. This also one of the reasons the revenue from the personal income tax has increased in respect to total tax revenue. Considering inflation rates in the Czech economy, it is apparent that during the analyzed period of 2008 - 2019, the fair value of the tax credits decreased by $17.63 \%$. The only amounts that show the opposite trend are deductions for children in the form of a tax credit. The graduation of amounts for children according to the number of children in the common household resulted in the situation in which the most significant increase occurred regarding the tax credit for the third and additional children, with a jump of almost $87 \%$ compared to the base year 2008 . The base year 2008 was selected for these analyses as the year that a large public finance reform was instituted, significantly incurring changes in the methods of calculating the personal income tax. Wage growth in the economy as well as inflation are other factors that will influence the increase of the tax burden and thus tax revenue in the coming years, a situation that will continue unless the existing tax rebates are indexed.

Another feature of this article was the construction of a model that reflects the dependence of tax revenue on the income tax of natural persons from employment in terms of relief for all taxpayers as well as the tax credit for parents with their first, second or third child. The key scientific hypothesis formulated in the introduction was not confirmed. The tax relief or tax credit did not show a negative effect on the tax revenue from the personal income tax in the Czech Republic during the analyzed period. In accordance with previous similar studies, two macroeconomics indicators were added to the model variables, i.e. the rate of registered unemployment and the pace of economic growth. In this case it can be stated that the existence of the tax credit for the second and third child has a positive influence and increases tax revenue. On the other hand, the rate of registered unemployment has a negative effect on the tax revenue. In the models describing the dependence of tax revenue on tax reliefs for the taxpayer or the tax credit for the first children, none of the assumptions of the regression model were met. Nevertheless, this aspect may be the subject of further research in the future.

When only the dependence of the share of the income tax of natural persons from employment in the total tax revenue to the taxpayer's relief was analyzed, it was found that the existence of reliefs for the taxpayer reduces that share, and if the state would like to increase the share in the tax revenue, one option is to decrease the relief for the taxpayer. A decrease in taxpayer relief 
is currently not being considered (year 2019), as requests for the annulment of the super-gross wage and a change in the calculation methodology are being formulated. If these changes are implemented, it can be expected that the nominal income tax would be set at higher rate, and the amounts of the tax relief or tax credit would also be different from those of the present time.

\section{References}

1. Abraham, F. (1999). A Policy Perspective on European Unemployment. Scottish Journal of Political Economy, 46 (4), 350-366. https://doi.org/10.1111/1467-9485.00138

2. Aidt, T. S., \& Jensen, P. S. (2009). The Taxman Tools up: An Event History Study of the Introduction of the Personal Income Tax. Journal of Public Economics, 93 (1-2), 160-175. https://doi.org/10.1016/j.jpubeco.2008.07.006

3. Andrasic, J., Kalas, B., Mirovic, V., Milenkovic, N., \& Pjanic. M. (2018). Econometric Modelling of Tax Impact on Economic Growth: Panel Evidence from OECD Countries. Economic Computation and Economic Cybernetics Studies and Research, 52 (4), 211-226, https://doi. org/10.24818/18423264/52.4.18.14

4. Andrlík, B. (2014). Measurement of Effectiveness of Personal Income Tax in the Tax System of the Czech Republic. Acta Univ. Agric. Silvic. Mendelianae Brun, 62 (2), 307-314. https://doi.org/10.11118/actaun201462020307

5. Angelopoulos, K., Angelopoulos, S., \& Malley, J. (2019). The Optimal Distribution of the Tax Burden over the Business Cycle. Macroeconomic Dynamics, 23 (6), 2298-2337. https://doi. org $/ 10.1017 /$ S1365100517000700

6. Belozyorov, S., \& Sokolovska, O. (2018). Personal Income Taxation and Income Inequality in Asia-Pacific: A Cross-country Analysis. Journal of Tax Reform, 4 (3), 236-249. https://doi. org/10.15826/jtr.2018.4.3.054

7. Bezdek, V., \& Stiller, V. (2000). Forecasting the Main Tax Revenues in the Czech Economy. Finance a úvere, 50 (2), 66-77.

8. Berger, T., \& Evaraert, G. (2013). Is the Impact of Labor Taxes on Unemployment Asymmetric? Macroeconomic Dynamics, 17 (1), 143-154. https://doi.org/10.1017/ S136510051100006X

9. Bird, R. M., \& Zolt, E. M. (2005). Redistribution via Taxation: The Limited Role of the Personal Income Tax in Developing Countries. Ucla Raw Review, 52 (6), 1627-1695.

10. Bohringer, C., Boeters, S., \& Feil, M. (2005). Taxation and Unemployment: an Applied General Equilibrium Approach. Economics Modelling, 22 (1), 81-108, http://dx.doi.org/ 10.1016/j.econmod.2004.05.002

11. Bonamente, M. (2017). Statistics and Analysis of Scientific Data. New York: Springer.

12. Brase, Ch. H., \& El-Iraki, A. (2019). Understanding Basics Statistics. Australia: Cengage.

13. Breuer, C. (2010). The Revenue Dynamics of Assessed Taxes in Germany. Working Paper.

14. Blundell, R. \& Shephard, A. (2012). Employment, Hours of Work and the Optimal Taxation of Low-Income Families. Review of Economic Studies, 79 (2), 481-510. https://doi. org/10.1093/restud/rdr034 
15. Caminada, K., \& Goudswaard, K. (1996). Progression and Revenue Effects of Income Tax Reform. International Tax and Public Finance, 3 (1), 57-66. https://doi.org/10.1007/ BF00400147

16. Cornia, G. C., Johnson, R. B., \& Nelson, R. D. (2017). Personal Income Tax Revenue Growth and Volatility: Lessons and Insights from Utah Tax Reform. Public Finance Review, 45 (1), 458-483. https://doi.org/10.1177/1091142116668255

17. Creedy, J., \& Germmell, N. (2015). Revenue-maximising Tax Rates and Elasticities of Taxable Income in New Zealand. New Zealand Economics Papers, 49 (2), 189-206. https://doi. org/10.1080/00779954.2014.893860

18. Czech Statistical Office. (2019). Main Macroeconomics Indicators. Retrieved February 9, 2019, from https://www.czso.cz/csu/czso/hmu_cr

19. Dolenc, P., Laporsek, S., \& Separovic, A. (2011). Does Labour Taxation Affect Unemploymet? Croatian Worker in International Perspective. Economic Research-Ekonomska Instrazivanja, 24 (3), 86-101. https://doi.org/10.1080/1331677X.2011.11517469

20. Eissa, N., \& Liebman, J. B. (1996). Labor Supply Response to the Earned Income Tax Credit. Quarterly Journal of Economics, 111 (2), 605-637. https://doi.org/10.2307/2946689

21. Eurostat. (2018). Shares of Environmental and Labour Taxes in Total Tax Revenues. Retrieved January 9, 2018, from https://ec.europa.eu/eurostat/web/products-datasets/-/ sdg_17_50

22. Financial Administration. (2019). Vývoj inkasa vybraných daní v České republice v letech 1993-2017. Retrieved April 1, 2019, from http://www.financnisprava.cz/cs/dane/analyzy-astatistiky/udaje-z-vyberu-dani

23. Fricke, H., \& Süssmüth, B. (2014). Growth and Volatility of Tax Revenues in Latin America. World Development, 54, 114-138. https://doi.org/10.1016/j.worlddev.2013.07.007

24. Friedrich, V., Maková, K., \& Široký, J. (2012). Testing the Predicative Ability of the Tax Progressiveness Indices (Using the Example of an Employee in the Czech Republic In 1993-2008). E \& M Ekonomie a Management, 15 (1), 4-16.

25. Fu, Z., Wu, L., \& Zhuang, Z. (2019). Labor Supply, Income Distribution and Tax Progressivity in a Search Model. B E Journal of Macroeconomics, 19 (1). https://doi. org/10.1515/bejm-2017-0185

26. Gale, W. G., \& Potter, S. R. (2002). An Economic Evaluation of the Economic Growth and Tax Relief Reconciliation Act of 2001. National Tax Journal, 55 (1), 133-186. https://doi. org/10.17310/ntj.2002.1.08

27. Hassler, U., \& Hosseinkouchack, M. (2015). Distribution of the Durbin-Watson Statistic in Near Integrated Processes. Empirical Economic and Financial Research: Theory, Methods and Practice, 48 (1), 421-436. https://doi.org/10.1007/978-3-319-03122-4_26

28. Havránek, T., Irsova, Z., \& Schwarz, J. (2016). Dynamic Elasticities of Tax Revenue: Evidence from the Czech Republic. Applied Economics, 48 (60), 5866-5881. https://doi.org/1 0.1080/00036846.2016.1186796 
29. Heathcote, J., Storesletten, K., \& Violante, G. L. (2017). Optimal Tax Progressivity: An Analytical Framework. Quarterly Journal of Economics, 132 (4), 1693-1754. https://doi. org/10.1093/qje/qjx018

30. Holko, M. (2019). Theory of Taxation and Tax Policy in OECD Countries. Ekonomista, 2 (1), 163-193.

31. Izák, V. (2011). Government Expenditures and Taxes Influence on the Economic Growth (Empirical Analysis). Politická ekonomie, 59 (2), 147-163. https://doi.org/10.18267/j.polek.778

32. Kotlán, I., \& Machová, Z. (2013). Interaction of Taxation, Government Expenditure and Economic Growth: Panel VAR Model for OECD Countries. Politická ekonomie, 61 (5), 623-638. https://doi.org/10.18267/j.polek.920

33. Krzikallová, K., \& Stř́lková, R. (2016). Labour-Intensive Services and Changes in Value Added Tax Revenue. Journal of Competitiveness, 8 (1), 5-18. https://doi.org/10.7441/ joc.2016.01.01

34. Kubátová, K., \& Jareš, M. (2011). Identification and Quantification of Tax Reliefs in the Czech Republic in the Year 2008. Politická ekonomie, 59 (4), 475-489. https://doi. org/10.18267/j.polek.800

35. Lee, M. (2016). On the Durbin-Watson Statistic Based on a Z-test in Large Samples. International Journal of Computational Economics and Econometrics, 6 (1), 114-121. https://doi. org/10.1504/IJCEE.2016.073370

36. Lee, Y., \& Gordon, R. H. (2005). Tax Structure and Economic Growth. Journal of Public Economics, 89 (5-6), 1027-1043. https://doi.org/10.1016/j.jpubeco.2004.07.002

37. McClave, J. T. \& Sincich, T. (2018). Statistics. New York: Pearson.

38. Mendoza, E. G., Razin, A., \& Tesar, L. L. (1994). Effective Tax Rates in Macroeconomics - Cross-Country Estimates of Tax Rates on Factor Incomes and Consumption. Journal of Monetary Economics, 34 (3), 297-323. https://doi.org/10.1016/0304-3932(94)90021-3

39. Morini, M., \& Pellegrino, S. (2018). Personal Income Tax Reforms: A Genetic Algorithm Approach. European Journal of Operational Research, 264 (3), 994-1004. https://doi. org/10.1016/j.ejor.2016.07.059

40. Nam, Ch. W., \& Zeiner, Ch. (2016). Effects of Tax Reform on Average Personal Income Tax Burden and Tax Progressivity in Germany under the Particular Consideration of Bracket Creep. Ejournal of Tax Research, 14 (3), 587-600.

41. Neverauskiene, O., Mieziene, R., \& Gataulinas, A. (2017). Evaluation of the Relationship between Labour Taxation and Unemployment: Case Study of Lithuania in the EU Context. Filosofija-Sociologija, 28 (4), 225-235.

42. OECD (2019). OECD Tax Database. http://www.oecd.org/tax/tax-policy/tax-database. htm\#pit Accessed 2 January 2019.

43. Oh, J. (2017). Are Progressive Tax Rates Progressive Policy? New York University Law Review, 92 (6), 1909-1976. 
44. Profeta, P., \& Scabrosetti, S. (2017). The Polical Economy of Taxation in Europe. Hacienda Publica Espanola-Review of Public Economics, 220 (1), 137-172. https://doi.org/10.7866/HPERPE.17.1.5

45. Shi, S., \& Wen, Q. (1999). Labor Market Search and the Dynamic Effects of Taxes and Subsidies. Journal of Monetary Economics, 43 (2), 457-495. https://doi.org/10.1016/s03043932(98)00064-6

46. Schneider, O., \& Jelínek, T. (2005). Distributive Impact of Czech Social Security and Tax Systems: Dynamics in Early 2000s. Prague Economics Papers, 3 (1), 221-237.

47. Sims, C. A. (1996). Macroeconomics and Methodology. Journal of Economics Perspectives, 10 (1), 105-120. https://doi.org/10.1257/jep.10. 1.105

48. Sobotovičová, S., \& Blechová, B. (2017). A Different Position of the Cz̨ech Republic Regions in Terms of Tax Revenues. In: 20th International Colloquium on Regional Sciences. 855-861. Kurdejov: Czech Republic.

49. Sorensen, P. B. (2004). Measuring the Tax Burden on Capital and Labour. Cambridge: MIT Press.

50. Splinter, D. (2019). Who Pays No Tax? The Declining Fraction Paying Income Taxes and Increasing Tax Progressivity. Contemporary Economic Policy, 37 (3), 413-426. https://doi. org/10.1111/coep.12407

51. Swank, D. (2016). Taxing Choices: International Competition, Domestic Institutions and the Transformation of Corporate Tax Policy. Journal of European Public Policy, 23 (4), 571-603. https://doi.org/10.1080/13501763.2015.1053511

52. Široký, J., Krajčová, J., \& Hakalová, J. (2016). The Taxation of Agricultural Land with the Use of Multi-criteria Analysis. Agricultural Economics-Zemedelska Ekonomika, 62 (5), 197-204. https://doi.org/10.17221/183/2015-AGRICECON

53. Teixeira, S. J., \& Ferreira, J. M. (2019). Enterpreneurial Artisan Products as Regional Tourism Competitiveness. International Journal of Entrepreneurial Behavior \& Research, 25 (4), 652-673. https://doi.org/10.1108/IJEBR-01-2018-0023

54. Tepperová, J., \& Pavel, J. (2016). Evaluation of the Impact of Selected Tax Reforms Influencing the Income of Individuals in the Czech Republic. Acta Universitatis Agriculturae et Silviculturae Mendelianae Brunensis, 64 (4), 1401-1407.

55. Vítek, L. (2012). Distributional Effects of Taxes and Benefit Reforms in the Czech Republic. International Journal of Economics and Management Engineering, 6 (11), 2976-2982.

56. Vítek, L., \& Pavel, J. (2013). Impact of Taxes on Redistribution in the Czech Republic. Acta Universitatis Agriculturae et Silviculturae Mendelianae Brunensis, 7 (61), 2931-2938.

57. Večerník, J. (2006). Income Taxes and Benefits among Czech Employees. Changes since 1989 and a Cross-national Comparison. Finance a íverr, 56 (1-2), 2-17.

58. Verbist, G., \& Figari, F. (2014). The Redistributive Effect and Progressivity of Taxes Revisited: An International Comparison across the European Union. Finanzarchiv, 70 (3), 405-429. https://doi.org/10.1628/001522114X684529 
59. Vlachý, J. (2008). A Dynamic Model of Personal Income Tax. E + M Ekonomika a Management, 11 (3), 85-93.

60. Yilmazkuday, H. (2017). Individual Tax Rates and Regional Tax Revenues: a cross-state Analysis. Regional Studies, 51 (5), 701-711. https://doi.org/10.1080/00343404.2015.1119266

61. Wilson, J. D. (1999). Theories of Tax Competition. National Tax Journal, 52 (2), 269-304.

62. Zimcik, P. (2016). Economic Growth and Budget Constraints: EU Countries Panel Data Analysis. Review of Economic Perspectives, 16 (2), 87-101. https://doi.org/10.1515/ revecp-2016-0007

63. Zubalová, A. (2015). Implementation Trends of the Credit Income Tax into the Personal Income Taxation in OECD Countries. In: 17th International Scientific Conference Finance and Risk. 262-267. Bratislava: Slovak Republic

\section{Contact information}

Ing. Michal Krajnak, Ph.D., MBA

VSB-Technical University of Ostrava

Faculty of Economics

Department of Accounting and Taxes

Czech Republic

E-mail:michal.krajnak@vsb.cz.

ORCID: 0000-0003-4924-3583 